九州大学学術情報リポジトリ

Kyushu University Institutional Repository

\title{
Meiotic Behavior, Capsule Setting and Seed Germination of Diploid and Polyploid Phalaenopsis amabilis
}

Wongprichachan, Prapassorn

Department of Horticultural Science, National Chiayi University

Shen, Tsai-Mu

Department of Horticultural Science, National Chiayi University

Huang, Kuang-Liang

Department of Horticultural Science, National Chiayi University

Okubo, Hiroshi

Faculty of Agriculture, Kyushu University

https://doi.org/10.5109/25198

出版情報：九州大学大学院農学研究院紀要. 57 (2)，pp.405-409，2012-09-20. Faculty of Agriculture, Kyushu University

バージョン：

権利関係 : 


\title{
Meiotic Behavior, Capsule Setting and Seed Germination of Diploid and Polyploid Phalaenopsis amabilis
}

\author{
Prapassorn WONGPRICHACHAN ${ }^{1}$, Tsai-Mu SHEN ${ }^{1 *}$, \\ Kuang-Liang HUANG ${ }^{1}$ and Hiroshi OKUBO
}

\author{
Laboratory of Horticultural Science, Division of Agronomy and Environmental Sciences, \\ Department of Agro-environmental Sciences, Faculty of Agriculture, \\ Kyushu University, Fukuoka 812-8581, Japan \\ (Received April 24, 2012 and accepted May 10, 2012)
}

\begin{abstract}
Ploidy levels, morphological traits in different ploidies, meiotic behavior and capsule settings in the interploid crossings in three cultivars of Phalaenopsis amabilis were investigated. Diploid, triploid and tetraploid cultivars were identified by flow cytometry. The stomatal density per unit area of the abaxial leaf surfaces was lower and stomatal sizes were bigger in the tetraploid than in the diploid and triploid cultivars. Almost all pollen mother cells (PMCs) of the diploid cultivar were divided into tetrads, whereas the triploid and tetraploid plants had numerous PMCs which were divided irregularly into sporads with a varying number of micronuclei. When the triploid plant was used as a female or male parent, the germination rate of the hybrids was low. It was shown that the size and density of stomata can be used as rapid techniques for identification of ploidy levels of $P$. amabilis, and the percentage of normal tetrads of PMCs can be a criterion for the selection of pollen donor plants.
\end{abstract}

Keywords: capsule setting, interploid crossings, meiotic behavior, Phalaenopsis amabilis, seed germination

\section{INTRODUCTION}

The genus Phalaenopsis comprises 45 to 63 species and has a wide geographic distribution ranging from the Himalayas of Northern India through Southeast Asia to Northern Australia (Christenson, 2001; Sweet, 1980). In general, relatively little was known about the genetics of orchids because of the high production cost owing largely to relatively long growing cycles (Kamemoto et al., 1999). Cross breeding with different ploidies is a challenge to the development of new hybrids, but the differences in chromosome numbers prevent zygote development after pollination (Singh and Hymowitz, 1987).

Species and hybrids in the genus of Phalaenopsis hold a high value in floriculture because of their graceful and long-lasting flowers. Although interspecific and intergeneric hybridizations have long been used for breeding of superior cultivars in Phalaenopsis orchids, only a few reports have described meiotic chromosome pairing in $\mathrm{F}_{1}$ hybrids (Arends, 1970; Bolaños-Villegas et al., 2008).

Phalaenopsis amabilis is an endemic ephiphytic orchid native to Lanyu Island, Taitung, Taiwan (Lin, 1988). Over the past few decades, it has been used extensively in breeding for Phalaenopsis hybrids and is now one of the most important species to the floriculture industries in Taiwan. However, little is known about their habitat and their ecology. It seems that there exist different ploidies in the species, which would have probably originated through crossing due to 2 n gamete formation or somaclonal variation during micropropagation.

This study aims to clarify the ploidy levels of $P$. ama-

\footnotetext{
${ }^{1}$ Department of Horticultural Science, National Chiayi University, Chiayi 60004, Taiwan, Republic of China

* Corresponding author (E-mail: tmshen@mail.ncyu.edu.tw)
}

bilis, morphological traits in different ploidies, meiotic behavior and capsule settings in the interploid crossings.

\section{MATERIALS AND METHODS}

\section{Plant materials}

Three cultivars of $P$. amabilis were collected from the Yu Pin Biological Technology Co., Ltd. and the Horticulture Technology Center, National Chiayi University, Chia-yi, Taiwan. They were cultivated in $10 \mathrm{~cm}$ diameter pots in a greenhouse at the Horticulture Technology Center, National Chiayi University, Chia-yi, Taiwan.

\section{Sample preparation and Giemsa staining for chro- mosome observation}

Growing root tips were pretreated with $2 \mathrm{mM}$ 8-hydroxyquinoline (Sigma-Aldrich, St. Louis) or $0.1 \%$ colchicine (Sigma-Aldrich) solution on a rotary shaker (100 rpm) for $5 \mathrm{~h}$ at $20^{\circ} \mathrm{C}$, and were then fixed in $95 \%$ ethanol-acetic acid $(3: 1 \mathrm{v} / \mathrm{v})$ for $24 \mathrm{~h}$ at $4^{\circ} \mathrm{C}$. Samples were digested with $1 \%$ (w/v) cellulase (Sigma-Aldrich) and $0.5 \%(\mathrm{w} / \mathrm{v})$ pectinase (Fluka) in $10 \mathrm{mM}$ of citrate buffer (Pedrosa et al., 2001). Digested samples were mounted on a slide with a droplet of 10\% Giemsa (SigmaAldrich), covered with a cover slide, and microscopically analyzed (Axio version Rel.4.5, Germany) with a CCD camera (Cannon A620, Japan).

\section{Preparation of nuclei and flow cytometry analysis of nuclear DNA content}

Extraction of nuclei and staining of DNA followed the method of Arumuganathan and Earle (1991) with some modifications. All procedures were done on ice. Leaf tissues (ca. 0.3-1.0 g) were sliced with razor blades into strips of less than $1 \mathrm{~mm}^{2}$ in $1 \mathrm{ml}$ extraction solution 
( $1 \mathrm{mM} \mathrm{MgSO}_{4}, 5 \mathrm{mM} \mathrm{KCl}, 0.5 \mathrm{mM}$ HEPES, $1 \mathrm{mg} / \mathrm{mL}$ dithiothreitol, $2.5 \mathrm{mg} / \mathrm{mL}$ Triton $\mathrm{X}-100, \mathrm{pH}$ 8.0) and extracted for $45 \mathrm{~min}$. After filtering through a $45 \mu \mathrm{m}$ Falcon cell strainer, $100 \mu \mathrm{L}$ of 4,6-diamidino-2-phenylindole (DAPI) $(1 \mathrm{mg} / \mathrm{mL})$ and $2.5 \mu \mathrm{L}$ of $500 \mu \mathrm{g} / \mathrm{mL}$ DNase-free RNase (Boehringer Mannheim, Indianapolis, IN) were added to each sample followed by $30 \mathrm{~min}$ incubation at $37^{\circ} \mathrm{C}$. Nuclei were analyzed directly after preparation using a Beckman (Germany) flow cytometer, equipped with an arc lamp. Each sample, at least 10,000 nuclei, was analyzed. Nuclear DNA content values were calculated using the mean values (in channel number) for the $2 \mathrm{C}$ nuclear peak of the sample divided by that of the standard multiplied by the nuclear DNA content of the standard. Nuclear DNA content values listed represented the mean 2C genome size for each cultivar. Relative DNA content was calculated by comparing the $2 \mathrm{C}$ peak in the flow karyogram with that of the Nicotiana tabacum, which were added as an internal reference (DNA content=11.70 pg / 2C) (Bennett and Leitch, 2004).

\section{Stomatal density and stomatal size}

The stomata measurements were taken from an imprint of the lower leaf surface (abaxial surface), obtained by applying clear finger-nail polish on the leaf, allowing it to dry, and peeling it off (Hamill et al., 1992). The imprint was mounted on a microscope slide with a drop of water to allow the analysis of the guard cells. The stomatal density average was calculated for each plant by counting stomata in 10 fields of view $\left(1 \mathrm{~mm}^{2}\right)$. The stomatal densities were measured at $100 \times$ magnification and stomatal sizes were measured at $40 \times$ magnification under a microscope (Axio version Rel.4.5, Germany) with a CCD camera (Cannon A620, Japan). For stomatal size, the study used 20 plants per cultivar while ten stomata per plant were measured.

\section{Sporad quantification in pollen mother cells (PMCs)}

To quantify the frequency of different types of sporads in each cultivar, pollen mother cells were stained with lactophenol-acid fuchsin solution (Lim et al., 2001). Pollinia from full-sized flower buds were fixed with a 95\% ethanol-glacial acetic acid (3:1 v/v) solution for $24 \mathrm{~h}$, hydrolyzed in $1 \mathrm{~N} \mathrm{HCl}$ for $1 \mathrm{~h}$ at $60^{\circ} \mathrm{C}$, rinsed three times with distilled water, and stained with a lactophenol-acid fuchsin solution. The material for observation was examined under a microscope (Axio version Rel.4.5, Germany) with a CCD camera (Cannon A620, Japan). One thousand PMCs were categorized according to the number of sporads, especially tetrads, at the end of the division II stage and at least three different plants were used for examination. Pictures were also taken using a digital camera (Cannon A620, Japan).

\section{Capsule setting and seed germination rate}

Reciprocal crossings of the cultivars were conducted. Ten flowers were used for each cultivar in one crossing. Capsules were harvested 115 days after pollination (DAP). Two weeks after the pollination, number of cap- sules was counted and survived capsules were counted 115 days after pollination. Seed viability was assessed using Alexander's staining process (Alexander, 1980). Pink or red stained seeds under a microscope were considered viable.

Three capsules per crossing were surface-sterilized for $20 \mathrm{~min}$ in 20\% (v/v) Clorox solution and 0.05\% Tween 20 and subsequently rinsed 3 times with sterilized distilled water. Seeds were germinated aseptically in $90 \times$ $15 \mathrm{~mm}$ diameter petri dishes containing $25 \mathrm{~mL}$ basal medium supplemented with Hyponex \#1 $2.5 \mathrm{~g} / \mathrm{L}$ (7N$6 \mathrm{P}_{2} \mathrm{O}_{5}-19 \mathrm{~K}_{2} \mathrm{O}$ ), myo-inositol $200 \mathrm{mg} / \mathrm{L}$, peptone $2 \mathrm{~g} / \mathrm{L}$, ammonium nitrate $\left(\mathrm{NH}_{4} \mathrm{NO}_{3}\right) 1 \mathrm{~g} / \mathrm{L}$, Potato $60 \mathrm{~g} / \mathrm{L}$, naphthalene acetic acid (NAA) $1 \mathrm{mg} / \mathrm{L}$, kinetin $0.5 \mathrm{mg} / \mathrm{L}$, indole-3-butyric acid (IBA) $0.5 \mathrm{mg} / \mathrm{L}$, activated charcoal $1 \mathrm{~g} / \mathrm{L}$ with $20 \mathrm{~g} / \mathrm{L}$ sucrose, and $10 \mathrm{~g} / \mathrm{L}$ agar. The $\mathrm{pH}$ value of the media was adjusted to 5.4 with $1 \mathrm{~N} \mathrm{KOH}$ or $\mathrm{HCl}$ prior to autoclave for $15 \mathrm{~min}$ at $121^{\circ} \mathrm{C}$. All cultures were incubated at $25 \pm 2^{\circ} \mathrm{C}$ in a $16 \mathrm{~h}$ photoperiod (cool-white fluorescent light lamps with a light intensity of $54 \mu \mathrm{mol} /$ $\mathrm{m}^{2} / \mathrm{s}$ ). The following materials from in vitro cultures were examined; each petri dish was examined 30 days after seed sowing under a stereoscopic microscope (Olympus SZX12, Olympus Optical Co. Ltd, Tokyo, Japan), and germinated seeds were counted. Percentages of seeds germinated for each treatment were averaged from five grids $\left(1 \mathrm{~cm}^{2}\right)$ randomly selected on each petri dish. Grids typically contained between 50 and 100 seeds each.

\section{Statistical analysis}

This experiment used a completely randomized design (CRD) in reciprocal crosses, and used the COSTAT 6.2 program (Cohort Software, Monterey, Calif., USA) for statistical analysis of the data looking at the least significant difference (LSD) multiple range test where $P \leqq 0.05$.

\section{RESULTS}

\section{Chromosome number and genome size}

Chromosome number from the somatic tissue (root tip) of the cultivars ranged from $2 \mathrm{n}=2 \mathrm{x}=38$ (diploid) for ' $16 \mathrm{~B}$ ', 2n=3x=57 (triploid) for 'M1503', and $2 \mathrm{n}=4 \mathrm{x}=76$ (tetraploid) for 'M1526' (data not shown). Mean of genome value in the first peak of '16B' : 'M1503' : 'M1526'

Table 1. Stomatal density and stomatal size from abaxial leaf surfaces of diploid and polyploid $P$. amabilis

\begin{tabular}{llccc}
\hline & & \multicolumn{3}{c}{ Stomatal } \\
\cline { 3 - 5 } Ploidy level & Cultivars & $\begin{array}{c}\text { density } \\
\text { No. of stoma } \\
\left.1 \mathrm{~mm}^{2}\right)\end{array}$ & $\begin{array}{c}\text { Length } \\
(\mu \mathrm{m})\end{array}$ & $\begin{array}{c}\text { Width } \\
(\mu \mathrm{m})\end{array}$ \\
\hline Diploid & $16 \mathrm{~B}$ & $17.01 \mathrm{a}^{\mathrm{z}}$ & $22.15 \mathrm{c}$ & $24.28 \mathrm{~b}$ \\
Triploid & M1503 & $16.47 \mathrm{a}$ & $24.69 \mathrm{~b}$ & $24.79 \mathrm{~b}$ \\
Tetraploid & M1526 & $10.78 \mathrm{~b}$ & $26.94 \mathrm{a}$ & $26.54 \mathrm{a}$ \\
\hline
\end{tabular}

${ }^{2}$ Mean separation within columns by LSD multiple range test at $P \leqq 0.05$. 

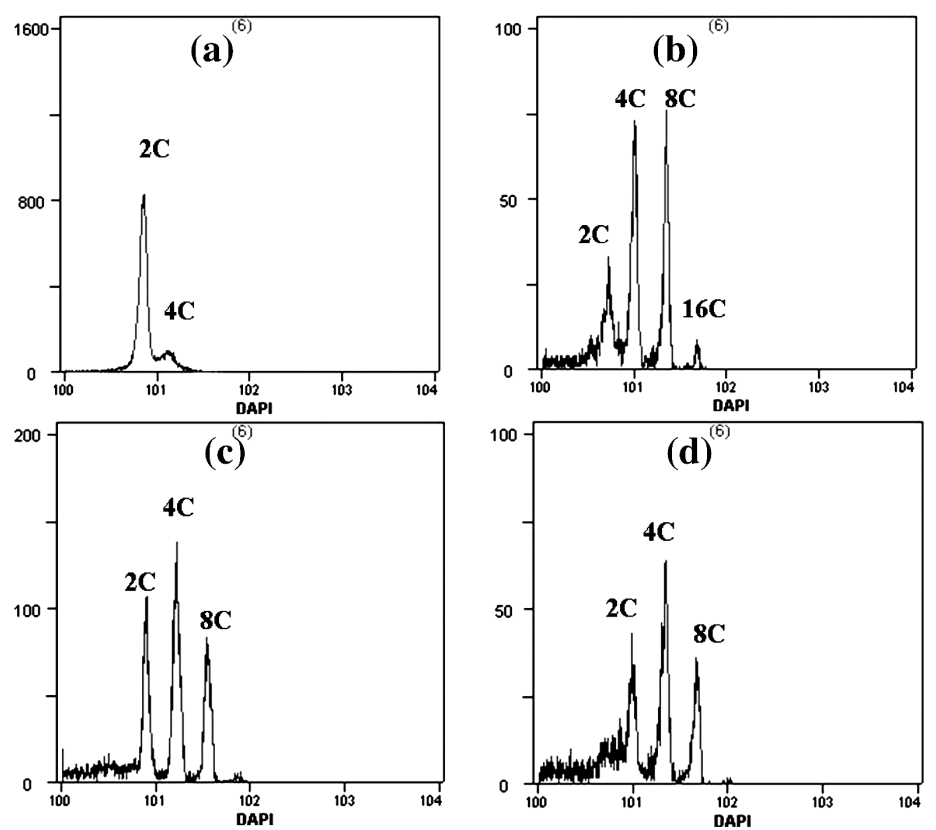

Fig. 1. Flow cytometric measurements of nuclear DNA levels of $P$. amabilis (a) Tobacco (Nicotiana tabacum), (b) '16B' (diploid), (c) 'M1503' (triploid) and (d) 'M1526' (tetraploid).

was $5.30: 7.94: 10.00$ (data not shown). The ratio was about $1: 1.50: 1.88$, indicating that the genome size of 'M1503' is 1.5 fold bigger and that of 'M1526' is 2 fold bigger than that of '16B' (Fig. 1).

\section{Stomatal density and size}

Stomatal densities in the diploid ('16B') and triploid ('M1503') were not significantly different, but higher than those in tetraploid ('M1526') (Table 1 and Fig. 1). Tetraploid 'M1526' had the longest and widest stomatas among the three cultivars (Table 1 and Fig. 2). Triploid 'M1503' had longer stomatas than diploid '16B', but the widths in diploid were similar to those of triploid.

\section{Sporad quantification in pollen mother cells}

Almost of all PMCs in '16B' were tetrads (97\%), whereas the tetrads in 'M1503' and 'M1526' were 33 and $63 \%$ of PMCs, respectively (Table 2 and Fig. 3 ). In addition, 'M1503' and 'M1526' exhibited irregular division varying numbers of micronuclei.

\section{Capsule setting and seed germination rate}

When diploid '16B' was a seed parent, capsule settings were $100 \%$ in all the crosses with diploid, triploid
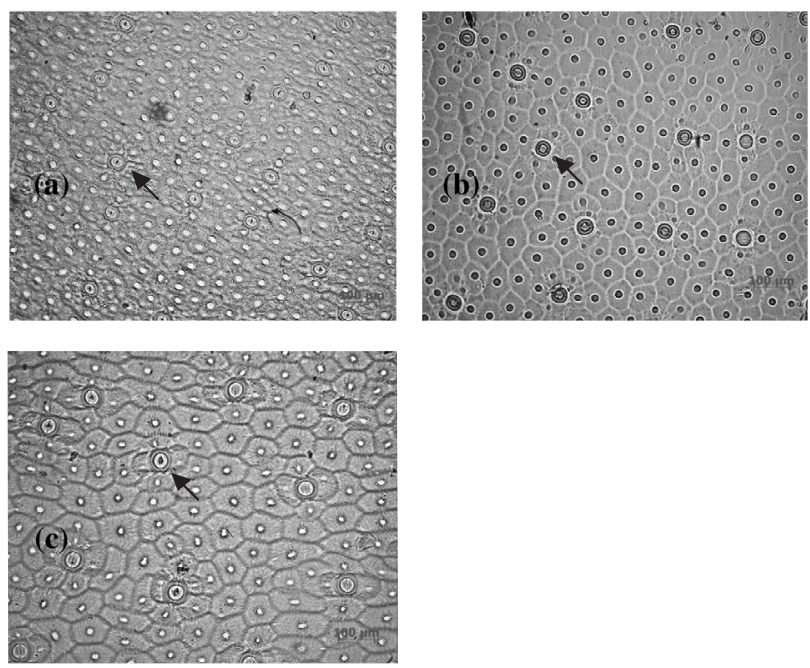

Fig. 2. Stomatal density on abaxial surface of leaves of $P$. amabilis. (a) '16B' (diploid) (b) 'M1503' (triploid) and (c) 'M1526' (tetraploid) Arrowheads point to stomata.

Table 2. Distribution of sporad types of diploid and polyploid P. amabilis observed by the staining of pollen mother cells with lactophenolacid fuchsin solution

\begin{tabular}{lllllllllr}
\hline \multirow{2}{*}{$\begin{array}{c}\text { Ploidy } \\
\text { level }\end{array}$} & Cultivars & \multicolumn{7}{c}{ Number (percentage) $)^{z}$ of pollen mother cells } \\
\cline { 3 - 9 } & & Monad & Dyad & Triad & Tetrad & Tetrad+1mcy & Tetrad+2mc & Tetrad+3mc & $\begin{array}{c}\text { Total sporocyte } \\
\text { observed }\end{array}$ \\
\hline Diploid & 16B & $5(0.42)$ & $12(1.01)$ & $2(0.17)$ & $882(97.05)$ & $11(1.35)$ & $0(0)$ & $0(0)$ & $1,185(100)$ \\
Triploid & M1503 & $0(0)$ & $0(0)$ & $0(0)$ & $429(33.00)$ & $268(20.62)$ & $219(18.04)$ & $346(28.35)$ & $1,217(100)$ \\
Tetraploid & M1526 & $1(0.06)$ & $2(0.12)$ & $0(0)$ & $1,021(62.75)$ & $243(14.94)$ & $230(14.14)$ & $130(7.99)$ & $1,627(100)$ \\
\hline
\end{tabular}

${ }^{\mathrm{z}}$ percentage of pollen mother cells observed

${ }^{y} \mathrm{mc}=$ micronucleus 
and tetraploid cultivars (Table 3). Length, width and weight of capsules were not significantly different among the crosses. Number of seeds per capsule was low in the cross with $2 \mathrm{X}$, but high in other crosses. The germination
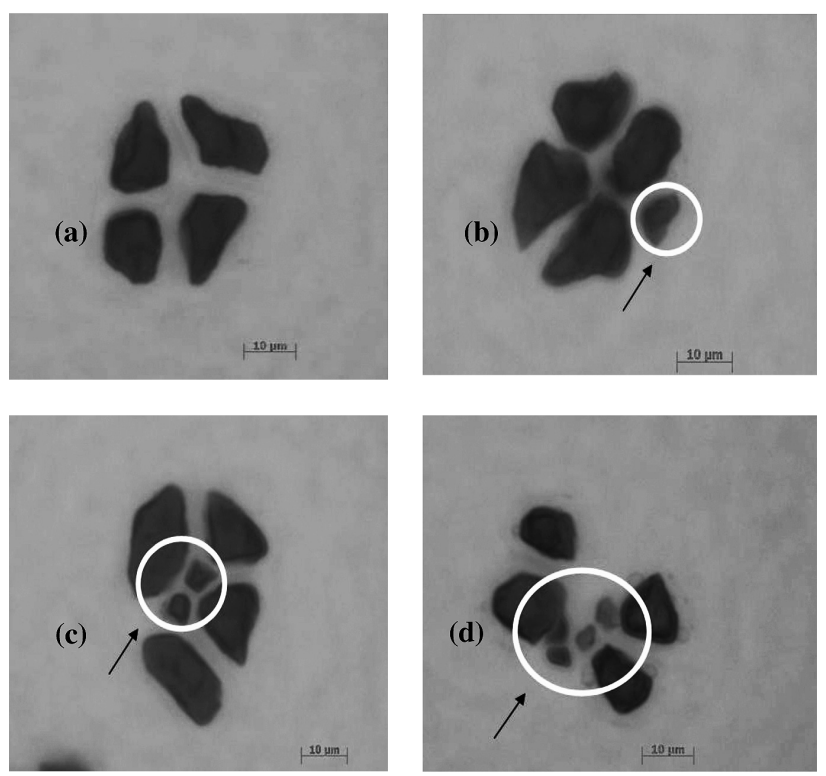

Fig. 3. Lactophenol-acid fuchsin staining of microspores in $P$. amabilis. (a) tetrad, (b) tetrad plus one micronuclei, (c) tetrad plus two micronuclei and (d) tetrad plus four micronuclei. Arrowheads point to micronuclei. rate was highest in the crosses with tetraploid 'M1526'.

In the crosses of triploid 'M1503', capsule settings were high (80-100\%) irrespective of the ploidies of pollen parents (Table 4). Capsule length, width and weight were highest with tetraploid 'M1526' among the crosses. Seed content per capsule was very abundant in this cross $(4 \mathrm{X} \times 3 \mathrm{X})$ with the highest germination rate.

Capsule settings were also high (80-100\%) in the crosses of tetraploid 'M1526' as female with diploid, triploid and tetraploid cultivars (Table 5). Length, width and weight of capsules, and seed number per capsule obtained from the crosses of $4 \mathrm{X}$ with $2 \mathrm{X}$ and with $4 \mathrm{X}$ were superior to those with $3 \mathrm{X}$. Germination rates was highest in the cross of $4 \mathrm{X} \times 2 \mathrm{X}$.

\section{DISCUSSION}

Polyploidy increases organ size in many species of dicots and monocots (Stebbins, 1971). Similarly, leaf size and flower numbers are greater in triploid than in diploid $P$. amabilis (data not shown). Sugiyana (2005) reported that tetraploid cultivars of Lolium multiflorum and $L$. perenne had significantly longer leaves than the diploid cultivars.

Stomata observation was shown to be reliable to identify ploidy levels in this study similar to the report by Beck et al. (2003) who found that high ploidy level plants had a lower density of stomata, and longer stomata was

Table 3. Capsule setting and seed germination rate of $P$. amabilis ' $16 \mathrm{~B}$ ' crossed with diploid and polyploid plants of $P$. amabilis

\begin{tabular}{|c|c|c|c|c|c|c|c|}
\hline \multicolumn{2}{|c|}{ Parents } & \multicolumn{4}{|c|}{ Capsule } & \multirow{2}{*}{$\begin{array}{l}\text { Seed content / } \\
\text { capsule }^{\mathrm{y}}\end{array}$} & \multirow{2}{*}{$\begin{array}{l}\text { Germination } \\
\text { rate }(\%)\end{array}$} \\
\hline Female & Male & setting (\%) & length $(\mathrm{cm})$ & width $(\mathrm{cm})$ & weight (g) & & \\
\hline \multirow[t]{3}{*}{$16 B(2 x)$} & $16 B(2 x)$ & 100 & $9.65 \mathrm{a}^{\mathrm{z}}$ & $1.19 \mathrm{a}$ & $4.95 \mathrm{a}$ & + & 19.90 \\
\hline & M1503 (3x) & 100 & $8.49 \mathrm{a}$ & $1.27 \mathrm{a}$ & $4.69 \mathrm{a}$ & +++ & 10.69 \\
\hline & M1526 (4x) & 100 & $9.19 \mathrm{a}$ & $1.20 \mathrm{a}$ & $5.12 \mathrm{a}$ & +++ & 49.37 \\
\hline
\end{tabular}

${ }^{2}$ Mean separation within columns by LSD multiple range test at $P \leqq 0.05$

${ }^{\mathrm{y}}$ Seed content per capsule: low $(+)$, abundant $(+++)$, very abundant $(+++++)$

Table 4. Capsule setting and seed germination rate of $P$. amabilis 'M1503' crossed with diploid and polyploid plants of $P$. amabilis

\begin{tabular}{|c|c|c|c|c|c|c|c|}
\hline \multicolumn{2}{|c|}{ Parents } & \multicolumn{4}{|c|}{ Capsule } & \multirow{2}{*}{$\begin{array}{l}\text { Seed content / } \\
\text { capsule }^{y}\end{array}$} & \multirow{2}{*}{$\begin{array}{l}\text { Germination } \\
\text { rate }(\%)\end{array}$} \\
\hline Female & Male & setting (\%) & length $(\mathrm{cm})$ & width $(\mathrm{cm})$ & weight (g) & & \\
\hline \multirow[t]{3}{*}{ M1503 (3x) } & $16 \mathrm{~B}(2 \mathrm{x})$ & 80 & $8.19 \mathrm{~b}^{\mathrm{y}}$ & $1.27 \mathrm{~b}$ & $5.16 \mathrm{~b}$ & ++ & 25.26 \\
\hline & M1503 (3x) & 80 & $7.24 \mathrm{c}$ & $0.96 \mathrm{c}$ & $2.78 \mathrm{c}$ & + & 2.85 \\
\hline & M1526 (4x) & 100 & $10.33 \mathrm{a}$ & $1.40 \mathrm{a}$ & $8.04 \mathrm{a}$ & +++++ & 34.19 \\
\hline
\end{tabular}

${ }^{\mathrm{z}}$ Mean separation within columns by LSD multiple range test at $P \leqq 0.05$

${ }^{\mathrm{y}}$ Seed content per capsule: low $(+)$, abundant $(+++)$, very abundant $(+++++)$

Table 5. Capsule setting and seed germination rate of $P$. amabilis 'M1526' crossed with diploid and polyploid plants of $P$. amabilis

\begin{tabular}{|c|c|c|c|c|c|c|c|}
\hline \multicolumn{2}{|c|}{ Parents } & \multicolumn{4}{|c|}{ Capsule } & \multirow{2}{*}{$\begin{array}{l}\text { Seed content / } \\
\text { capsule }^{y}\end{array}$} & \multirow{2}{*}{$\begin{array}{l}\text { Germination } \\
\text { rate }(\%)\end{array}$} \\
\hline Female & Male & setting (\%) & length $(\mathrm{cm})$ & width $(\mathrm{cm})$ & weight (g) & & \\
\hline \multirow[t]{3}{*}{$\operatorname{M1526}(4 \mathrm{x})$} & $16 B(2 x)$ & 80 & $10.82 \mathrm{a}^{\mathrm{y}}$ & $1.36 \mathrm{a}$ & $7.70 \mathrm{a}$ & +++++ & 63.02 \\
\hline & $\operatorname{M1503(3x)}$ & 100 & $9.27 \mathrm{~b}$ & $1.17 \mathrm{~b}$ & $5.26 \mathrm{~b}$ & +++ & 36.72 \\
\hline & M1526 (4x) & 100 & $10.31 \mathrm{a}$ & $1.35 \mathrm{a}$ & $7.56 \mathrm{a}$ & +++++ & 43.82 \\
\hline
\end{tabular}

${ }^{2}$ Mean separation within columns by LSD multiple range test at $P \leqq 0.05$

${ }^{y}$ Seed content per capsule: low $(+)$, abundant $(+++)$, very abundant $(+++++)$ 
found in higher polyploidy plants (Evans, 1955) in Trifolium pratense, T. repens and Medicago sativa, in Lolium perenne and L. multiflorum (Speckmann et al., 1965), and in Bromus inermis (Geok-Yong and Dunn, 1973). The length and frequency of stomata on abaxial leaf surfaces were examined as rapid techniques for identification of the ploidy level of $P$. amabilis. The results are similar to those reported by Beck et al. (2003) who showed that, in Acacia mearnsii, the density of stomata per leaf surface was shown to decrease significantly as the ploidy level increased.

Our pollination results (Tables $3-5$ ) seem to indicate that capsule settings were high in reciprocal crosses of different ploidy levels of $P$. amabilis, whereas crosses involving aberrant pollen cells led to low seed yield. Irregular sporads had been previously reported in interspecific hybrids of Phalaenopsis (Arends, 1970; BolañosVillegas et al., 2008; Shindo and Kamemoto, 1963), but inversions or translocations were not observed and pollen viability was not investigated. In this study, $P$. amabilis plants with a low percentage of normal tetrads or having a high percentage of tetrads with polar nuclei, failure of seed setting after cross pollination was commonly exhibited, similarly to the reports of Arends (1970) and Bolaños-Villegas et al. (2008). However, the finding of inversions and translocations implies the existence of additional hybridization barriers in this species that has not been considered before. Abnormal cytological behavior of the pollen mother cells of an autotetraploid Vaccinium elliottii also resulted in reduced pollen viability (Dweikat and Lyrene, 1991). Probably, a better indication of pollen fitness was the dominant division pattern of PMCs during division II. Doritaenopsis hybrids with a low frequency of tetrads tended to show asymmetric segregation, chromosomal aberrations, and poor pollen viability.

In this study, it was shown that measurement of the size and density of stomata on abaxial leaf surfaces is used as rapid techniques for identification of the ploidy levels of $P$. amabilis plants, and that the percentage of normal tetrads of PMCs is an indicator for the selection of pollen donor plants. High interploid crossability in $P$. amabilis may open new roads to Phalaenopsis breeding.

\section{REFERENCES}

Alexander, M. P. 1980 A versatile staining for pollen, fungi yeast and bacteria. Stain Technol., 55(1): 13-18

Arends, J. C. 1970 Cytological observations on genome homology in eight interspecific hybrids of Phalaenopsis. Genetica, 41: $88-100$

Arumuganathan, K. and E. D. Earle 1991 Estimation of nuclear DNA content of plants by flow cytometry. Plant Mol. Biol. Rep., 9: 229-233

Beck, S. L., R. W. Dunlop and A. Fossey 2003 Stomatal length and frequency as measure of ploidy level in black wattle, Acacia mearnsii (de Wild). Bot. J. Linn. Soc., 141: 177181

Bennett, M. D. and I. J. Leitch 2004 Plant DNA C-values database (release 3.0, Dec. 2004) http://www.kew.org/cvalues/ homepage.html.

Bolaños-Villegas, P. B., W. C. Shih and F. C. Chen 2008 Meiotic chromosome behavior and capsule setting in Doritaenopsis hybrids. J. Amer. Soc. Hort. Sci., 133: 107-116

Christenson, E. A. 2001 Phalaenopsis: a Monograph. Timber Press, Portland, Oregon

Dweikat, I. M. and P. M. Lyrene 1991 Induced tetraploidy in a Vaccinium elliottii facilitates crossing with cultivated high bush blueberry. J. Amer. Soc. Hort. Sci., 116: 1063-1066

Evans, A. 1955 The production and identification of polyploids in red clover, white clover and lucerne. New Phytol., 54: 149-162

Geok-Yong, T. and G. M. Dunn 1973 Relationship of stomatal length and frequency and pollen-grain diameter to ploidy level in Bromus inermis Leyss. Crop Sci., 13: 332-334

Hamill, S. D., M. K. Smith and W. A. Dodd 1992 In vitro induction of banana autotetraploidy by colchicine treatment of micropropagated diploids. Aust. J. Bot., 40: 887-896

Kamemoto, H., T. D. Amore and A. Kuehnle. 1999 Breeding Dendrobium Orchids in Hawaii. Univ. of Hawaii Press, Honolulu

Lim, K. B., M. S. Ramanna, J. H. de Jong, E. Jacobsen and J. M. van Tuyl 2001 Indeterminate meiotic restitution (IMR): a novel type of meiotic nuclear restitution mechanism detected in interspecific lily hybrids by GISH. Theor. Appl. Genet., 103: $219-230$

Lin, T. P. 1988 Native Species of Taiwan vol. 2, Southern Materials Center, Inc., Taipei, Republic of China

Pedrosa, A., M. F. Jantsch, E. A. Moscone, P. F. Ambros and D. Schweizer 2001 Characterisation of pericentromeric and sticky intercalary heterochromatin in Ornithogalum longibracteatum (Hyacinthaceae). Chromosoma, 110: 203-213

Shindo, K. and H. Kamemoto 1963 Karyotype analysis of some species of Phalaenopsis. Cytologia, 28: 390-398

Singh, R. J. and T. Hymowitz 1987 Intersubgeneric crossability in the genus Glycine Willd. Plant Breed., 98: 171-173

Speckmann, G. J., J. J. Post and H. Dijkstra 1965 The length of stomata as an indicator for polyploidy in rye-grasses. Euphytica, 14: 225-230

Stebbins, G. L. 1971 Chromosomal Evolution in Higher Plants 1st ed. Edward Arnold Pub., London

Sugiyana, S. I. 2005 Polyploidy and cellular mechanisms changing leaf size: comparison of diploid and autotetraploid populations in two species of Lolium. Ann. Bot., 96: 931-938

Sweet, H. R. 1980 The genus Phalaenopsis. Day Printing Corp, Pomona, California 